Article

\title{
Technology Portfolio and Role of Public Research Institutions in Industry 4.0: A Case of South Korea
}

\author{
SungUk Lim ${ }^{1}$ and Junmo Kim ${ }^{2, *}$ \\ 1 Department of Industrial Engineering, Dae-Jin University, 1007 Hoguk-Ro, Gyeonggi, Pocheon 11159, Korea \\ 2 Department of Public Admin, Konkuk University, Neung Dong Ro 120, Gwang-Jin-Gu, Seoul 05029, Korea \\ * Correspondence: junmokim@konkuk.ac.kr or junmokim@unitel.co.kr
}

Received: 7 June 2019; Accepted: 21 June 2019; Published: 28 June 2019

Featured Application: Management and Public Policy oriented research on the realignment of research organizations.

\begin{abstract}
The 4th industrial revolution has been a hot topic in various societies for several overlapping reasons. It may be a huge wave for researchers to navigate through. In this context, research institutions are not different from major industrial sectors, in that both consider the 4th revolution a major turning point as well as a threat. Today's industries and research institutions are knowledge-intensive in nature. Consequently, their potential for survival depends on scientific and technological aspects as well as their organizational dimension. This study analyzes 25 major public research institutions in South Korea, located in the DaeDuk area, based on their technological capability for organizational and expert evaluation. It also proposes a matching scheme between research institutions and research topics related to the 4 th industrial revolution.
\end{abstract}

Keywords: 4th industrial revolution; industry 4.0; AHP; QFD; matching

\section{Introduction}

The 4th industrial revolution has been a hot topic in various societies for several overlapping reasons. It may be a huge wave for researchers to navigate through. In this context, research institutions are not different from major industrial sectors, in that both consider the 4th revolution a major turning point as well as a threat [1,2]. Today's industries and research institutions are knowledge-intensive in nature. As a result, their potential for survival depends on scientific and technological aspects as well as their organizational dimension [3,4]. This implies that research institutions' organizational and manpower strategy is one of the key aspects in understanding such institutions $[5,6]$. If the characteristic of the 4th industrial revolution can be understood as increasing connectiveness with information technology, countries that are aiming, by certain degrees, at reconfiguration of research institutions, whether they are public or private in their origin, may find similar problem definitions and solutions. This research intended to find a clue with a case study of research institutions in Korea with potential implications for other countries.

In this context, this study analyzes 25 major public research institutions located in the DaeDuk area in South Korea, based on their technological capability for organizational as well as expert evaluation. The study also proposes a matching scheme between research institutions and research topics related to the 4 th industrial revolution. 


\section{Literature Review}

\subsection{The Industry 4.0 Context and Product/Technology Life Cycle Theory}

Industry 4.0 has been a keyword not only in business circles, but also in general media and academic circles [7]. Industry 4.0, or the 4th industrial revolution, has been on the agenda, despite the fact that the concept has often been either overstated or misrepresented to encompass diverse meanings [8]. Instead of analyzing the concept in depth, this study focuses on its core element: the connectivity of things [1]. The use of Information Technology (IT) has made this connectivity possible. This implies that, if there had been an alternative for the connectivity, it could be a medium other than IT.

While connectivity is the core element of the 4th industrial revolution [9], technology life cycle and product life cycle theories still hold their validity even for Industry 4.0 [10]. Proposed by Vernon in 1966, the product life cycle theory shows that there are product flows among country groups based on how early a country can initiate a new movement. Advanced industrial nations start the waves, which then flow into less developed countries. The technology life cycle theory follows the same logic, but focuses on technology flow [11] (Figure 1).

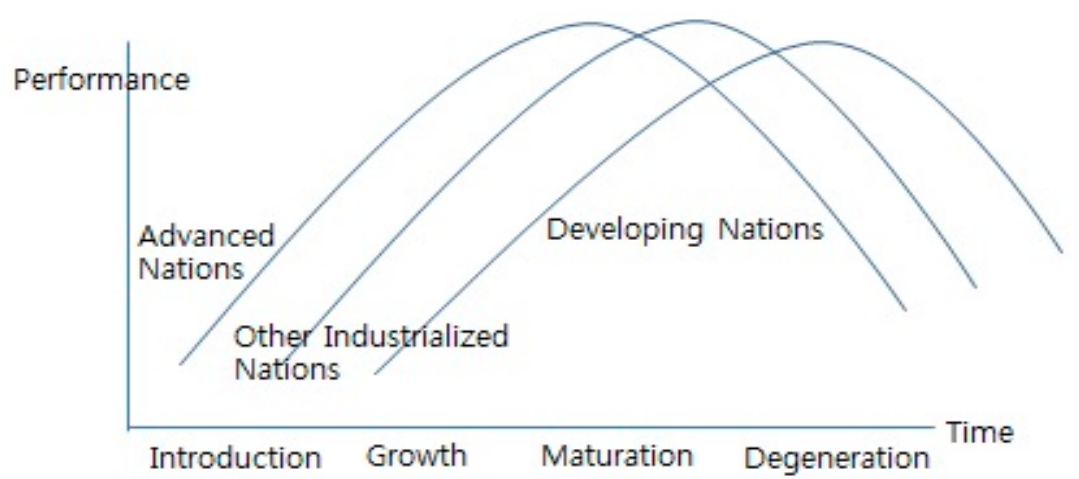

(Source: Raymond Vernon 1966: “International Investment and International Trade in the Product Cycle" The Quarterly Journal of Economics MIT Press/adapted and re-drawn from the original article)

Figure 1. A typical technology life cycle model.

\subsubsection{Differing Temperature Between Country Groups}

In the Industry 4.0 context, both the theories still make sense. For a country like the Philippines, the accepted meaning of the 4th industrial revolution is far different from that of the European countries [12]. The Philippines is still going through the so-called IT revolution or the 3rd industrial revolution by participating in the field of IT-related manufacturing and increasing its presence in the field. The case would be the same, if not much more intensive, in Vietnam [13], for example, where a good portion of Samsung smartphones has been assembled.

Based on this logic [14], it would be reasonable to infer that the 4th industrial revolution will take the form of a series of waves, as predicted by the technology life cycle or product life cycle theory. Consequently, the requirements for adapting to the 4th industrial revolution will vary across countries $[15,16]$, and so will the roles of universities and research organizations.

\subsection{2. "Leave us Alone" (Pure Research) vs. Entrepreneurial Research Model}

There have been successful cases of transformation involving research communities, universities, and firms. Cases from the Basque area of Spain are typical examples. The entrepreneurial research model, called the CIC marGUNE (the Co-operative Research Centre into High-performance Manufacturing), showed that technological research institutions and universities worked well with regional industries with the sponsorship of the government for upgrading industrial manufacturing processes [17]. 
Compared to the traditional "stand-alone" type research, which will find its final application fields at the terminal stage, the Basque model shows a concurrent collaboration among players in research and production [18]. This can be viewed as a harbinger for the forthcoming " 4 th industrial revolution" era spirit of collaboration. Additionally, cases like the Basque have an implication for other countries and regions that are seriously looking at the transformation of research institutions and industries into the 4 th industrial revolution.

\subsection{Changing Role of Public Research Institutions}

\subsubsection{Changing Role of Public Research Institutions}

The technology life cycle theory, as explained in the previous section, has provided insights for understanding the dynamics between countries in different groups. Like other developing countries, South Korea also had its own needs for technology development. The first type of need was related to the high costs of technology transfer from advanced nations. Vernon's international division of labor, which covers the technology life cycle, does not sufficiently explain the cost side of international technology transfer $[19,20]$. This does not mean that the theory is deficient; rather, it is reasonable to argue that the cost side was treated as hidden [21]. Thus, it would also be sensible to infer that if the costs of technology transfer exceed the traditional level, a country will have greater incentives for technology development [22,23].

The second type of need may arise from the potential restrictions on buyers that constrain their use of the technology. If the costs of bearing the restrictive clauses outweigh the costs of indigenous development, a technology-importing country is likely to opt for indigenous development.

It was in this context that public research institutions were established for supporting technology development in South Korea in the 1970s. The roles of public research institutions have changed over time with economic growth, allowing for a generalization of their roles with potential applications in other countries.

Column B in Table 1 shows the typical area in which public research institutions in South Korea have been engaged in since the 1970s. With increased economic development, the role of and expectations from public research institutions have also been strengthened.

Table 1. Stages of technology development cooperation.

\begin{tabular}{|c|c|c|c|c|c|c|c|}
\hline \multicolumn{3}{|c|}{ Pre-Competition } & \multicolumn{5}{|c|}{ Competition Stage } \\
\hline \multicolumn{3}{|c|}{ R\&D Cooperation } & \multicolumn{3}{|c|}{ Technical Cooperation } & \multicolumn{2}{|c|}{$\begin{array}{c}\text { Manufacturing/Marketing } \\
\text { Cooperation }\end{array}$} \\
\hline A & B & $\mathrm{C}$ & D & $\mathrm{E}$ & $\mathbf{F}$ & G & $\mathbf{H}$ \\
\hline $\begin{array}{l}\text { Univ. } \\
\text { centered } \\
\text { research } \\
\text { funded by } \\
\text { private } \\
\text { entities }\end{array}$ & $\begin{array}{l}\text { Gov't-industry } \\
\text { cooperation } \\
\text { project in } \\
\text { which univ } \\
\text { and public } \\
\text { research } \\
\text { institutions } \\
\text { participate }\end{array}$ & $\begin{array}{l}\text { arrangement } \\
\text { based on } \\
\text { private firms }\end{array}$ & $\begin{array}{l}\text { a venture } \\
\text { capital } \\
\text { investment } \\
\text { within a } \\
\text { big } \\
\text { company }\end{array}$ & $\begin{array}{l}\text { a non-equity } \\
\text { technological } \\
\text { arrangement } \\
\text { between firms } \\
\text { on selective } \\
\text { areas }\end{array}$ & $\begin{array}{c}\text { inter-firm } \\
\text { technical } \\
\text { arrangement } \\
\text { which } \\
\text { includes a } \\
\text { multiple types } \\
\text { of cross } \\
\text { licensing of } \\
\text { technology }\end{array}$ & $\begin{array}{c}\text { a joint venture } \\
\text { or a } \\
\text { comprehensive } \\
\text { R\&D, } \\
\text { manufacturing, } \\
\text { and marketing } \\
\text { consortium }\end{array}$ & $\begin{array}{l}\text { a licensing } \\
\text { agreement } \\
\text { or } \\
\text { marketing } \\
\text { arrangement }\end{array}$ \\
\hline
\end{tabular}

(Source: Adapted from OECD Science, Technology and Industry Outlook 2012, 2014).

\subsubsection{Performance Review Requirements}

Performance evaluation of public research institutions had been based mainly on performance review of their research projects until the 1980s. Starting from the 1990s, a comprehensive watershed came under the governance of public research organizations for two reasons [24,25]. The first was the expansion of government budget allocated to different research functions, under which public organizations could receive direct or indirect funds by participating in specific research projects. This brought in some sort of scrutiny in the management of the research budget. Second, by the time 
this reform was initiated, there were 22 government-funded research institutions, and the central government wanted to raise their budgetary allocation. The approach of project-based systems (PBS) was introduced in 1996 because of these two reasons.

Under the PBS, the Ministry of Finance would allocate funds to each public research institution for paying a share of salaries (usually between $30 \%$ and $80 \%$ ) and for covering research budget, which had direct costs and overhead cost elements. After introducing the PBS, the government constituted a governing body named National Science \& Technology Research Council for the 22 government-funded research institutions; the Council still exists, albeit with some modifications in terms of its structure and functions. In December 2005, the government promulgated a new law for national research and development projects, titled Government Performance and Review Act. The Act designated the jurisdiction of the evaluation of the public research organizations at the Ministry of Finance, which was formerly at the National Science and Technology Research Council. One peculiar feature was that after the Ministry of Finance assumed this control, the emphasis was more on general management evaluation than on research-related evaluation.

Reflecting the Ministry of Finance's lack of attention to research institutions, in 2013, the government transferred its control tower function of the evaluation of research institutions to the Ministry of Science and Technology.

\subsubsection{New Roles in the 4th Industrial Revolution}

With the 4th industrial revolution becoming a hot topic in policy circles, the role of public research institutions in South Korea became an issue in 2018. The Ministry of Science and Technology asked public research institutions to prepare their own "Role \& Responsibility" (R\&R) statements, which the institutions duly completed in 2018. The Ministry of Finance then introduced a real challenge, by proposing to link these institutions to their new roles in the context of the 4th industrial revolution [26-28]. This study identifies a way to enhance the unique contribution of public research institutions to the waves of the 4 th industrial revolution.

\section{Methodology}

\section{Data and Methodology}

In order to fulfill the aim of the study, this research employed an extensive data of the 25 public research institutions in Korea during summer and fall of 2018. As for details, first, this research acquired organizational, man power-related data, and pay structure of the institutions. Second, this study acquired performance-related data that were published to have validity. Third, by processing the two data sets, this research produced a AHP survey text, which has generated new data to be analyzed in the research. Then, this study utilized three types of methods. First, a three-stage analytical hierarchy process (AHP) technique was employed to set up an in-depth analysis. Second, an organizational analysis of all the 25 public research institutions was performed by using their manpower-related data. Third, this study utilized the quality function deployment (QFD) analysis to match the potential roles of research institutions with topics under the 4th industrial revolution. Lastly, this study linked the AHP and QFD scores to derive implications for the institutions and their roles in the context of the 4th industrial revolution.

The AHP analysis (Table 2) was carried out to assess the existing data. While it is possible to gather and analyze institution-level performance data, it is not easy to evaluate articles and patents in pure numbers. The method will urge experts to assign weight to individual institutions by looking at "all possible" performance data of the institutions. The AHP analysis was conducted with 25 experts who have been active in the research community for more than 20 years after their Ph.D. This study conducted a three-stage AHP survey to obtain relative weights of factors, which will be multiplied to organizational performance data from the 25 public institutions. AHP participants were asked to give weights at the three levels from the first stage to the third so that their averaged weighting was to be 
applied to the existing performance data of the 25 institutions. The first round produced a result of scientific/engineering excellence (0.669), excellence in operation/management (0.126), and efficiency in manpower and social values (0.205), which was then divided to be narrowed down to the next two stages.

Table 2. AHP weighting elements.

\begin{tabular}{|c|c|c|}
\hline 1st Stage & 2nd Stage & 3rd Stage \\
\hline \multirow[b]{2}{*}{ Scientific/Engineering Excellence } & $\begin{array}{c}\text { Necessity for research } \\
\text { Levels of research objectives }\end{array}$ & \multirow[b]{2}{*}{$\begin{array}{l}\text { Articles/patens per researcher } \\
\text { Profitability of outcomes } \\
\text { Growth potentials o research } \\
\text { Spin-off potentials }\end{array}$} \\
\hline & Excellence in research & \\
\hline \multirow{4}{*}{ Excellence in Operation/Management } & Innovation strategy & \multirow{4}{*}{$\begin{array}{c}\text { R\&D intensity } \\
\text { R\&D manpower } \\
\text { R\&D cooperation } \\
\text { R\&D investment } \\
\text { Organizational efficiency } \\
\text { R\&D budget efficiency }\end{array}$} \\
\hline & R\&D effectiveness & \\
\hline & Validity of Research & \\
\hline & Efficiency in budget & \\
\hline Efficiency in Man power \& social values & $\begin{array}{l}\text { Socioeconomic perspective } \\
\text { Public interest perspective } \\
\text { Future change Adapatability } \\
\text { Infra structure }\end{array}$ & \\
\hline
\end{tabular}

QFD is a quality management technique used to match consumer demand requirements and product specifications, and later, to check the affinity between different categories. In this study, QFD was utilized to link research institutions and their potential contributions to research topics related to the 4th industrial revolution.

After completing both the AHP and QFD analyses, we plotted their results to link research institutions and their potential contribution to the 4th industrial revolution. The focus was on finding those institutions that scored high on both analyses. These organizations can serve as the mediating entity for collaborative research in the 4 th industrial revolution.

\section{Findings}

\subsection{Organizational Dynamics Analysis}

We aimed to forecast manpower changes in five years from 2019 to 2024 . We found that approximately $21 \%$ of researchers are retiring due to age limits. This had tremendous implications in the functioning of a research institution. Currently, most of the 25 public research organizations had a reverse pyramid structure, where the composition of senior researchers takes the "top heavy" part. This also implies that in the next five years, if no special changes happen, younger Ph.Ds. will occupy the top positions, which will bring the organizational shape back to the "normal" pyramid type until the same organizations turn into a reverse pyramid shape in the future. This point necessitates a retooling of manpower structure in these institutions in the 4th industrial revolution era so that research organizations may not naturally follow the cyclical changes from normal pyramid to reverse pyramid shape. In fact, empirical findings have confirmed the point.

Another way of interpreting the implication for the organizational shape is based on the data this study analyzed. While it is difficult to determine who-Senior researchers or junior researchers-Contribute more to organizational performance in a cold context, because different ways of proving will always override the opposite hypothesis, Table 3 shows an indirect implication. 
Table 3. Comparison between senior and junior researchers.

\begin{tabular}{clcc}
\hline Composition & & Number of Articles & Number of Patents \\
\hline Senior Level & Pearson Coefficient & 0.298 & 0.914 \\
Junior Ph.D., level & Pearson Coefficient & 0.27 & 0.495 \\
Lower level & Pearson Coefficient & 0.202 & 0.610 \\
\hline Senior Level Annual salary/man & Pearson Coefficient & -0.26 & -0.154 \\
Junior Ph.D., level Annual salary/man & Pearson Coefficient & -0.262 & -0.244 \\
Lower level Annual salary/man & Pearson Coefficient & -0.157 & -0.203 \\
\hline
\end{tabular}

The upper part of Table 3 shows that seniority matters, because senior researchers excelled in both articles and patents. However, considering the bottom part of the table expressed in "pure" money terms, there was no difference across the three groups. It could mean that we need researchers from all three age brackets to achieve better results. This coincides with the academic finding of the "I" shape organization model for research institutes.

\subsection{AHP Analysis Using the Pre-Announced Performance Data}

Table 4 presents a partial example of preannounced performance data of the institutions. While it is seemingly organized data-wise, it is, in fact, not feasible to derive implications, because the value or impact of articles and patents of each organization, on average, is underrepresented. That is why this study employs the AHP-type value-assessing method.

Table 4. Institutional performance data.

\begin{tabular}{|c|c|c|c|c|c|c|c|c|}
\hline \multirow{3}{*}{ Results } & \multicolumn{6}{|c|}{ Excellence of Research } & \multicolumn{2}{|c|}{$\begin{array}{l}\text { Potential for } \\
\text { Market Success }\end{array}$} \\
\hline & \multicolumn{4}{|c|}{ 1. Articles, Patents } & \multirow{2}{*}{$\begin{array}{l}\text { 2.Profitability } \\
\text { Of Research } \\
\text { Outcomes } \\
\text { Running } \\
\text { Patents(B) }\end{array}$} & $\begin{array}{l}\text { Growth } \\
\text { Potential ff }\end{array}$ & \multicolumn{2}{|c|}{ Business Feasibility } \\
\hline & $\begin{array}{l}\text { Academic } \\
\text { Articles } \\
\text { per } \\
\text { Researcher }\end{array}$ & $\begin{array}{c}\text { Patents } \\
\text { Application } \\
\text { per } \\
\text { Researcher }\end{array}$ & \multicolumn{2}{|c|}{$\begin{array}{c}\text { Patents Registration per } \\
\text { Researcher }\end{array}$} & & $\begin{array}{c}\text { Tech } \\
\text { Transfer } \\
\text { Contracts } \\
\text { per } \\
\text { Researcher }\end{array}$ & \multicolumn{2}{|c|}{$\begin{array}{c}\text { Paid Tech Transfer } \\
\text { Contracts per } \\
\text { Researcher }\end{array}$} \\
\hline Mean & 0.57 & 0.17 & \multicolumn{2}{|c|}{0.15} & 0.65 & 0.03 & \multicolumn{2}{|c|}{0.03} \\
\hline Min & 0.00 & 0.00 & \multicolumn{2}{|c|}{0.00} & 0.00 & 0.00 & \multicolumn{2}{|c|}{0.00} \\
\hline Median & 0.34 & 0.14 & \multicolumn{2}{|c|}{0.13} & 0.52 & 0.03 & \multicolumn{2}{|c|}{0.02} \\
\hline \multirow[b]{3}{*}{ Results } & \multicolumn{2}{|c|}{$\begin{array}{l}\text { Effectiveness of research } \\
\text { related resources }\end{array}$} & \multicolumn{2}{|c|}{ Validity of research activities } & \multicolumn{2}{|c|}{ Efficiency in Budget } & \multicolumn{2}{|c|}{$\begin{array}{l}\text { Efficiency in } \\
\text { Manpower } \\
\text { management }\end{array}$} \\
\hline & $\begin{array}{c}\mathrm{R} \& \mathrm{D} \\
\text { intensity }\end{array}$ & $\begin{array}{l}\text { R\&D } \\
\text { Manpower } \\
\text { proportion }\end{array}$ & $\begin{array}{c}\text { R\&D } \\
\text { cooperation }\end{array}$ & $\begin{array}{c}\text { R\&D } \\
\text { Investment } \\
\text { intensity }\end{array}$ & $\begin{array}{l}\text { Budget } \\
\text { efficiency }\end{array}$ & $\begin{array}{l}\text { R\&D Budget } \\
\text { efficiency }\end{array}$ & Man powe & efficiency \\
\hline & $\begin{array}{l}\text { Degrees Of } \\
\text { patent use }\end{array}$ & $\begin{array}{c}\text { Total } \\
\text { number of } \\
\text { R\&D related } \\
\text { personnel }\end{array}$ & $\begin{array}{c}\text { \# of } \\
\text { Cooperative } \\
\text { Research } \\
\text { Projects } \\
\text { Across } \\
\text { institutions } \\
\text { Per } \\
\text { researcher }\end{array}$ & $\begin{array}{l}\text { Amount of } \\
\text { Sustainably } \\
\text { Secured } \\
\text { Research } \\
\text { Budget Per } \\
\text { researcher }\end{array}$ & $\begin{array}{l}\text { Ratio of Total } \\
\text { Current } \\
\text { operating } \\
\text { Budget over } \\
\text { Total Budget }\end{array}$ & $\begin{array}{l}\text { Total Direct } \\
\text { Research } \\
\text { Budget Per } \\
\text { researcher }\end{array}$ & $\begin{array}{l}\% \text { of Full } \\
\text { time } \\
\text { emploees }\end{array}$ & $\begin{array}{l}\text { Salary } \\
\text { Per } \\
\text { person }\end{array}$ \\
\hline
\end{tabular}

By multiplying the AHP results of weighting to the existing data, we obtained a performance portfolio of the 25 institutions (Table 5). 
Table 5. AHP results.

\begin{tabular}{ccc}
\hline Grouping & Ranking & Converted Scores \\
\hline A Group & $1-9$ & $94.69-81.32$ \\
B Group & $10-16$ & $78.94-71.10$ \\
C Group & $17-21$ & $68.53-60.51$ \\
D Group & $22-25$ & $59.85-54.47$ \\
\hline
\end{tabular}

\subsection{QFD Results}

With the QFD analysis (Tables 6 and 7), a matching between the 4th industrial revolution-related research topics and research institutions was made. It can be understood that the higher the number, the more the relatedness of the institution to the research topic. In Table 6, research organizations such as the KIST, ETRI, and KIMM are listed as the key institutions to play the central role in research related to the 4th industrial revolution.

Table 6. Matching between institutions and topics related to the 4th industrial revolution (QFD analysis).

\begin{tabular}{|c|c|c|c|c|c|c|c|c|c|c|c|c|c|c|c|c|c|c|c|c|c|c|c|c|c|c|}
\hline & \multicolumn{26}{|c|}{ Relatedness Btwn Institutions (See Table 7) and 4th Revolution Topics } \\
\hline & $\underset{\sim}{\stackrel{\theta}{\theta}}$ & 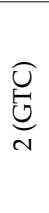 & $\underset{\infty}{\stackrel{\theta}{\theta}}$ & 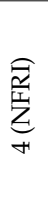 & 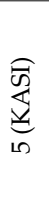 & 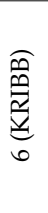 & $\underset{\sim}{\stackrel{\theta}{\theta}}$ & $\underset{\infty}{\underset{\infty}{\operatorname{s}}}$ & 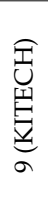 & $\begin{array}{l}\widehat{\vartheta} \\
\underset{|c|}{\mid c} \\
\stackrel{0}{-}\end{array}$ & $\begin{array}{l}\widehat{\Xi} \\
\text { 己 } \\
己 \\
=\end{array}$ & 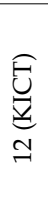 & 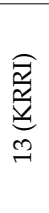 & 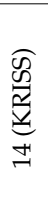 & 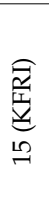 & $\underset{\underbrace{}}{\underset{\Downarrow}{\xi}}$ & 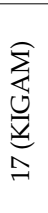 & 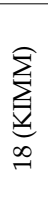 & 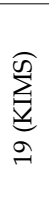 & 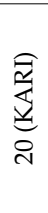 & 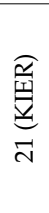 & 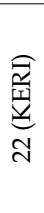 & $\underset{\vec{v}}{\stackrel{\theta}{\sigma}}$ & $\underset{\underset{\sim}{\Xi}}{\stackrel{\Xi}{E}}$ & 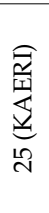 & 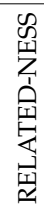 \\
\hline Big Data & 3 & & 1 & & & & 9 & & & & & & & & & & & & & & & & & & & 13 \\
\hline Communications & & & & & & & & & & 9 & & & & & & & & & & & & & & & & 9 \\
\hline A.I. & & & & & & & 1 & & & 3 & & & & & & & & & & & & 3 & & & & 7 \\
\hline Autonomous vehicle & & & & & & & & & 1 & & & & & & & & & 3 & & & & & & & & 4 \\
\hline Drones) & & & & & & & & & 1 & & & & & & & & & 3 & 1 & 1 & & & & & & 6 \\
\hline Health & & & & & & 1 & & 3 & & & & & & & 1 & 1 & & & & & & 1 & 1 & 1 & & 9 \\
\hline Smart city & 1 & & & & & & & & & & & 9 & 3 & & & & & & & & & & & & & 13 \\
\hline Virtual reality & & & & & & & & & & 3 & & & & & & & & & & & & & & & & 3 \\
\hline Robots & & & 3 & & & & & & 3 & & & & & & & & & 9 & 3 & & & & & & & 18 \\
\hline Semiconductor & 9 & & & & & & & & & 3 & & & & & & & & & 3 & & & & & & & 15 \\
\hline material & 3 & & & & & & & & 3 & 1 & & & & & & & & & 1 & & & & & & & 8 \\
\hline Medicine & & & & & & 9 & & 3 & & & & & & & & & & & & & & & 3 & & & 15 \\
\hline energy & 1 & 1 & & 1 & & & & & & & & & & & & & & & & & 9 & & 3 & & 9 & 24 \\
\hline Fitness & 17 & 1 & 4 & 1 & 0 & 10 & 10 & 6 & 8 & 19 & 0 & 9 & 3 & 0 & 1 & 1 & 0 & 15 & 8 & 1 & 9 & 4 & 7 & 1 & 9 & \\
\hline
\end{tabular}

One possible interpretation comes from the very nature of the 4th industrial revolution, where different fields are expected to come together for integration of oriented research fields; this clearly testifies that IT, machinery, and an interdisciplinary institution (KIST) could be the best fit.

This fitness relationship between research institutions and research topics related to the 4th industrial revolution is presented in detail in Figure 2. Taking AHP scores and QFD scores as the horizontal and vertical axes, respectively, Figure 2 shows that the institutions that have obtained high scores in both criteria can be regarded as the center for collaborative research in the context of the 4th industrial revolution. These institutions were KIST, KIMM, and ETRI, all of which can be characterized as institutions with integration role as one of their key functions in their original mission statement-based tasks. 
Table 7. Index of research institutions.

\begin{tabular}{cc}
\hline 1 & KIST (Korea Institute of Science and Technology) \\
\hline 2 & GREEN TECH CENTER (Green Technology Center) \\
3 & KBSI (Korea Basic Science Institute) \\
4 & NFRI (National Fusion Research Institute) \\
5 & KASI (Korea Astronomy and Space Science Institute) \\
6 & KRIBB (Korea Research Institute of Bioscience \& Biotechnology) \\
7 & KISTI (Korea Institute of Science and Technology Information) \\
8 & KIOM (KOREA INSTITUTE OF ORIENTAL MEDICINE) \\
9 & KITECH (Korea Institute of Industrial Technology) \\
10 & ETRI (Electronics and Telecommunications Research Institute) \\
11 & NSRI (National Security Research Institute) \\
12 & KICT (Korea Institute of Civil Engineering and Building Technology) \\
13 & KRRI (Korea Railroad Research Institute) \\
14 & KRISS (Korea Research Institute of Standards and Science) \\
15 & KFRI (Korea Food Research Institute) \\
16 & WIKIM (World Institute of Kimchi) \\
17 & KIGAM (Korea Institute of Geoscience and Mineral Resources) \\
18 & KIMM (Korea Institute of Geoscience and Mineral Resources) \\
19 & KIMS (Korea Institute of Materials Science) \\
20 & KARI (Korea Aerospace Research Institute) \\
21 & KIER (Korea Institute of Energy Research) \\
22 & KERI (Korea Electrotechnology Research Institute) \\
23 & KRICT (Korea Research Institute of Chemical Technology) \\
24 & KIT (Korea Institute of Toxicology) \\
25 & KAERI (Korea Atomic Energy Research Institute) \\
\hline
\end{tabular}

\section{QFD scores}

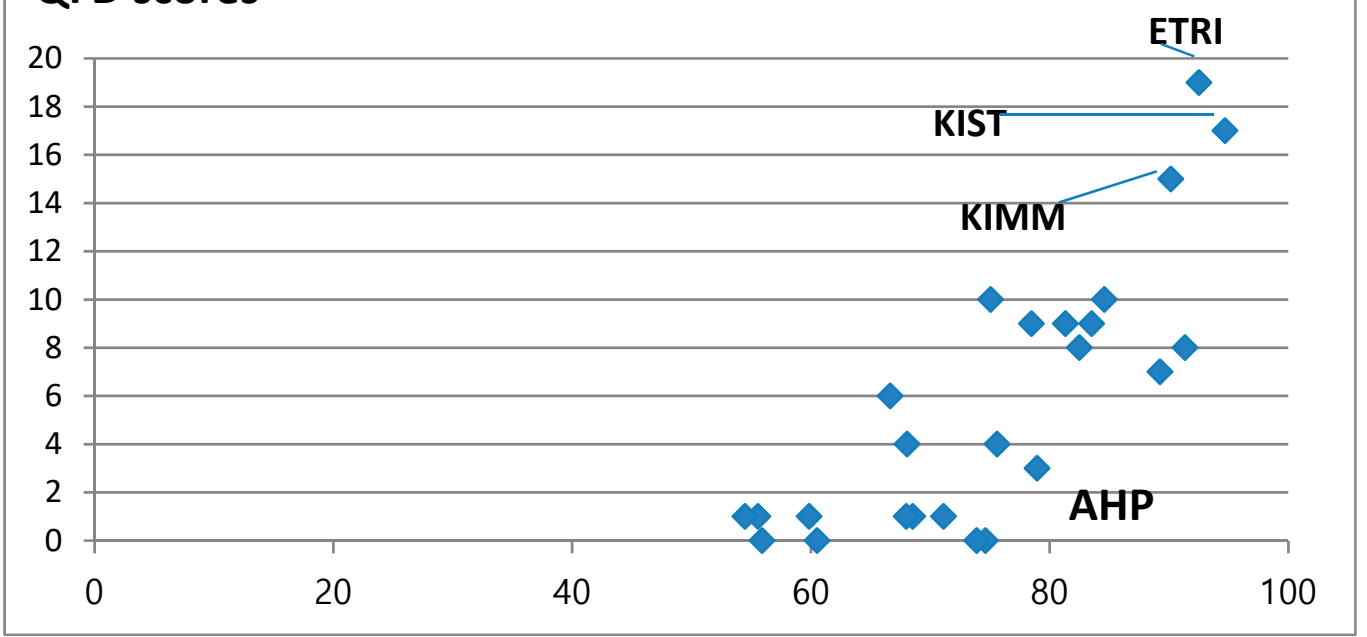

Figure 2. Fitness relationship between research institutions and the research topic of the 4th industrial revolution.

\section{Discussion}

As shown in this paper, the 4th industrial revolution is presenting a huge challenge as well as an opportunity to different levels of organizations including research institutions $[29,30]$. This paper, noting the salience, tried to capture the changing momentum of the 25 public research institutions in South Korea. In doing so, for going beyond the already existing performance measures, this study utilized the AHP expert survey to plot organizational performance and used organizational analysis to find inflows and outflows of manpower in the institutions. 
This study found several key elements that are applicable to other countries too. First, independent to the research institutions' scientific and technological capabilities at the current period, the organizations can be transformed by just changing their manpower structure, as if a machine undergoes a major refit.

- This study suggests that there should be a non-conventional recruitment process in the future following the "I" shape organization structure. Knowing the characteristic of the 4th industrial revolution which emphasizes connectiveness with information technology, countries that are aiming, by certain degrees, at reconfiguration of research institutions, whether they are public or private in their origin, may find similar problem definitions and solutions that have been described in this research. In addition, many analytical tools seem to rearrange those institutions, which this research tried to overcome by using expert level AHP analysis.

Second, through the QFD analysis of matching, the study found that research topics related to the 4th industrial revolution can be unevenly distributed among institutions, while most of them can still contribute to the analysis. This implies that the 4th industrial revolution, due to its nature, predesignates the kind of institutions that can function as integration control towers.

- In other words, research on the 4 th industrial revolution can be carried out by establishing a key institution, which will lead a group of participating research institutions. For example, in an autonomous vehicle case, it would be reasonable to find that either an IT area institution or a machine-based institution takes the leading role as a control tower, while other participating institutions follow the lead. This, in some sense, perfectly dovetails with the nature of the 4th industrial revolution, which needs connectedness between and among fields.

Third, although this study tried to present a ranking-based result from the AHP, it did not intend to foster a relative ranking system; rather, the intention was to augment the capability of interpreting the existing performance data of research institutions [31,32].

- As more and more research institutions and company research units are being retooled to meet the requirements of the 4th industrial revolution [33,34], this study tried to shed light on a new avenue to design interdisciplinary research programs $[35,36]$, which can be applied in other contexts too.

Author Contributions: J.K. designed the overall research plan and methodology, sampling framework for the research institutions, and wrote the manuscript. S.L. performed AHP and QFD analysis. Both authors together prepared the AHP questionnaire and indepth interviews of researchers.

Funding: This research received no external funding.

Conflicts of Interest: The authors declare no conflict of interest.

\section{References}

1. Schwab, K. The Fourth Industrial Revolution. World Economic Forum Public Discussions on the 4th Industrial Revolution Include the Following Forums. Available online: https://www.brookings.edu/blog/brown-centerchalkboard/2017/04/11/surfing-the-4th-industrial-revolution-artificial-intelligence-and-the-liberal-arts/ (accessed on 20 May 2019).

2. West, D.M. The Future of Work; The Brookings Institution: Washington, DC, USA, 2018.

3. Moretti, E. The New Geography of Jobs; First Mariner Books; Mariner Books: New York, NY, USA, 2013.

4. Womack, J.P.; Jones, D.T.; Roos, D. The Machine That Changed the World: The Story of Lean Production; Rawson Associates: New York, NY, USA, 1990.

5. Brynjolfsson, E. The Second Machine Age: Work, Progress, and Prosperity in a Time of Brilliant Technologies, 1st ed.; W. W. Norton \& Company: New York, NY, USA, 2016.

6. Palley, T. From Crisis to Stagnation: The Destruction of Shared Prosperity and the Role of Economics; Cambridge University Press: Cambridge, UK, 2012.

7. Boyer, R. The present crisis. A trump for a renewed political economy. Rev. Political Econ. 2013, 25, 1-3. [CrossRef]

8. Duperrin, B. Industry 4.0: The Dark Side of the Digital Enterprise. Available online: http://www.duperrin. com/english/2016/08/25/industry-4-0-digital-enterprise/ (accessed on 6 May 2019). 
9. Mainstream, B. Industry 4.0, The New Industrial Revolution: How Europe Will Succeed; Roland Berger: Munich, Germany, 2014; Available online: http://www.rolandberger.com/media/pdf/ (accessed on 6 May 2019).

10. Moretti, E. The New Geography of Jobs; Mariner Books: Wilmington, DE, USA, 2013.

11. Schumpeter, J.A. The Theory of Economic Development; Oxford University Press: New York, NY, USA, 1912.

12. Koch, M. Roads to Post-Fordism: Labor Markets and Social Structures in Europe; Routledge: Abingdon-on-Thames, UK, 2017.

13. Galbraith, J.K. History of Economics: The Past as the Present, 1st ed.; David \& Charles: Exeter, UK, 1987.

14. Ross, A. The Industries of the Future; Reprint edition; Simon \& Schuster: New York, NY, USA, 2017.

15. Kelly, K. The Inevitable: Understanding the 12 Technological Forces That Will Shape Our Future; Penguin Books: London, UK, 2017.

16. Piore, M.J.; Sabel, C. The Second Industrial Divide; Basic Books: New York, NY, USA, 1984.

17. Maidagan, X.; López de Lacalle, L.N.; Sánchez, J.A.; Lamiki, A.; Maidagan, E.; Cabanes, S. Entrepreneurial research model, CIC marGUNE: A case study. J. Sci. Ind. Res. 2008, 67, 272-276.

18. Barrio, H.G.; Moran, I.C.; Ealo, J.A.; Barrena, F.S.; Beldarrain, T.O.; Zabaljauregui, Mi.C.; Zabala, A.M.; Arriola, P.A.; Lopez de Lacalle, L.N. A reliable machining process by means of intensive use of modelling and process monitoring: Approach 2025. DYNA 2018, 93, 689-696.

19. Robinson, J. Essays in the Theory of Economic Growth; Macmillan: London, UK, 1962.

20. Minsky, H.P. Stabilizing an Unstable Econom; McGraw-Hill: New York, NY, USA, 2008.

21. Kim, J. Manufacturing or service? Market saturation and cycles of over-investment as a clue to future of service economies. Technol. Forecast. Soc. Chang. 2010, 78, 1345-1355. [CrossRef]

22. Vernon, R. The product cycle Hypothesis in a new international environment. Oxf. Bull. Econ. Stat. 1979, 41, 255-267. [CrossRef]

23. Vernon, R.; Wells, L.T. International trade and International investment in the product life cycle. Q. J. Econ. 1966, 81, 190-207. [CrossRef]

24. Hill, C.W.L. International Business Competing in the Global Marketplace, 6th ed.; McGraw-Hill: New York, NY, USA, 2007; p. 168.

25. Boyer, R. Is a finance-led growth regime a viable alternative to Fordism? A preliminary analysis. Econ. Soc. 2000, 29, 111-145. [CrossRef]

26. Shoujun, L. Economic crisis and regulation theory: review of international conference of research \& regulation 2015. World Rev. Political Econ. 2016, 7, 145-153.

27. Kim, J. Are countries ready for the new meso revolution? Testing the waters for new industrial change in Korea. Technol. Forecast. Soc. Chang. 2018, 132, 34-39. [CrossRef]

28. Minsky, H.P.; Whalen, C.J. Economic Insecurity and the Institutional Prerequisites for Successful Capitalism; Working Paper No. 165; Jerome Levy Economics Institute: Annandale-On-Hudson, NY, USA, 1996.

29. Piketty, T. Capital in the 21st Century; Belknap Press, An Imprint of Harvard University Press: Cambridge, MI, USA, 2014.

30. Nelson, R.R. Research on productivity growth and productivity differences: Dead ends and new departures. J. Econ. Lit. Am. Econ. Assoc. 1981, 19, 1029-1064.

31. Nelson, R.R. The Sources of Economic Growth; Harvard University Press: London, UK, 1996.

32. Baumol, W.J.; Nelson, R.R.; Wolff, E.N. Convergence of Productivity: Cross-National Studies and Historical Evidence; Oxford University Press: Oxford, UK, 1994.

33. Sabel, C.; Zeitlin, J. Historical alternatives to mass production: Politics, markets and technology in nineteenth-century industrialization. Past Present 1985, 108, 133-176. [CrossRef]

34. Kim, J.; Yoo, C.W. Why 'design' does not work well for cluster policy: With the implications for Science and Technology (S\&T) manpower policy. Int. J. Technol. Manag. 2007, 38, 321-338.

35. Audretsch, D.B. Technological regimes, industrial demography and the evolution of industrial structures. Ind. Corp. Chang. 1997, 6, 49-82. [CrossRef]

36. Piore, M.J. Beyond Markets: Sociology, street-level bureaucracy, and the management of the public sector. Regul. Gov. 2011, 5, 145-164. [CrossRef]

(C) 2019 by the authors. Licensee MDPI, Basel, Switzerland. This article is an open access article distributed under the terms and conditions of the Creative Commons Attribution (CC BY) license (http://creativecommons.org/licenses/by/4.0/). 